\title{
Mycophenolic acid inhibits the phosphorylation of nuclear factor- $k B$ and Akt in renal tubular epithelial cells
}

\author{
FANG ZENG, HUI-QUN QIN, WEI-JIA XU, MING-DAN ZHENG, HONG-TAO HU and HUA SHUI \\ Department of Nephrology, Zhongnan Hospital, Wuhan University, Wuhan, Hubei 430071, P.R. China
}

Received December 30, 2014; Accepted September 25, 2015

DOI: $10.3892 / \mathrm{mmr} .2015 .4526$

\begin{abstract}
Renal tubulointerstitial injury induced by albumin overload is a critical stage during the progression of renal interstitial fibrosis and progression of chronic renal diseases. Inosine-5'-monophosphate dehydrogenase inhibitor mycophenolate mofetil (MMF), a pro-drug of mycophenolic acid (MPA), is known to attenuate the progression of renal interstitial fibrosis; however, the underlying molecular mechanisms of the anti-fibrotic effects of derivatives of MMF have not yet been studied. The present study assessed the effects of the MPA on renal tubular epithelial cells. Transforming growth factor beta 1 (TGF- $\left.\beta_{1}\right)$ has been indicated to have a central role in the underlying molecular mechanisms of renal fibrosis; furthermore, nuclear transcription factor $-\kappa \mathrm{B}(\mathrm{NF}-\kappa \mathrm{B})$ is a transcription factor associated with the production of inflammatory cytokines, cell proliferation and apoptosis. In addition, the Akt signaling pathway has important roles in cell proliferation, differentiation, metabolism and apoptosis. The present study subjected the NRK52E rat kidney epithelial-derived cell line to albumin overload, which resulted in an increase in TGF- $\beta_{1}$ production as well as phosphorylation of Akt and the binding activity of NF- $\kappa \mathrm{B}$ to the promoter region of the TGF- $\beta_{1}$ gene, which was, however, reduced following pre-incubation of the cells with MPA. In addition, the effects of albumin were partially blocked by Ly294002, a specific inhibitor of Akt. In conclusion, the results of the present study suggested that MPA may exert its anti-fibrotic effects by inhibiting the upregulation of TGF- $\beta_{1}$ and the activation of NF- $\kappa \mathrm{B}$ following albumin overload, which may be partly dependent on the Akt pathway.
\end{abstract}

Correspondence to: Professor Hua Shui, Department of Nephrology, Zhongnan Hospital, Wuhan University, 169 Donghu Road, Wuchang, Wuhan, Hubei 430071, P.R. China

E-mail: shuihua2005@aliyun.com

Key words: mycophenolic acid, renal tubular epithelial cells, transforming growth factor $\beta 1$, nuclear transcription factor- $\kappa \mathrm{B}, \mathrm{Akt}$ signaling pathway

\section{Introduction}

The process of chronic renal diseases is typically accompanied with progressive renal fibrosis and the inhibition of fibrogenesis appears to be an attractive therapeutic target. Re-absorption of albumin by renal epithelial cells is important in the progression of renal tubular fibrosis caused by proteinuria (1). Mycophenolate mofetil (MMF), a pro-drug of mycophenolic acid (MPA), is one of the most frequently used immunosuppressive drugs for the prophylaxis of allograft rejection after renal, cardiac or liver transplantation. It is known that MPA is a potent, selective, non-competitive and reversible inhibitor of inosine-5'-monophosphate dehydrogenase. MPA inhibits not only the proliferation of lymphocytes, but also that of other mesenchymal cells (2-4). Transforming growth factor beta 1 (TGF- $\beta_{1}$ ) has a central role in fibrosis. Following combination of TGF- $\beta_{1}$ with its receptor, numerous signaling pathways are activated, including the Smad signaling pathway and the phosphoinositide-3 kinase (PI3K)/Akt pathway (5-7). Nuclear factor- $\mathrm{\kappa B}(\mathrm{NF}-\kappa \mathrm{B})$ is a transcription factor associated with the production of inflammatory factors, cell proliferation and apoptosis, which is involved in numerous processes of inflammatory signal transduction. Activation of the transcription factor NF- $\mathrm{\kappa B}$ is known to drive renal inflammation and fibrosis (8). Akt, a member of the serine/threonine protein kinase superfamily and the PI3K/Akt signaling pathway, has important roles in cell proliferation, differentiation, metabolism and apoptosis (9).

In spite of previous evidence of albumin-induced expression of TGF- $\beta_{1}$ and NF- $\kappa \mathrm{B}$, this mechanism has remained to be demonstrated in renal epithelial cells (10). The present study assessed the effects of MPA on NRK52E rat renal epithelial cell line in order to test the hypothesis that MPA inhibits albumin-induced expression of TGF- $\beta_{1}$ and activation of NF- $\mathrm{KB}$ in renal epithelial cells through the Akt pathway.

\section{Materials and methods}

Chemicals and reagents. The NRK52E normal rat kidney epithelial-derived cell line was obtained from the American Type Culture Collection (CRL-1571; Manassas, VA, USA). Dulbecco's modified Eagle's medium, nutrient mixture F-12 (DMEM/F12; 1:1), fetal bovine serum (FBS) and trypsin/EDTA solution were purchased from GE Healthcare (Little Chalfont, UK). TRIzol reagent were purchased from Invitrogen (Thermo Fisher Scientific, Waltham, MA, USA). 
Primers were obtained from Sangon Biological Engineering Technology and Services (Shanghai, China). Rabbit anti-rat phosphorylated (p)-Akt monoclonal antibody (cat. no. 4060) and rabbit anti-rat $\beta$-actin monoclonal antibody (cat. no. 4970) were purchased from Cell Signaling Technology, Inc. (Danvers, MA, USA). Nuclear proteins were extracted using the N-Extract kit (Sigma-Aldrich, St. Louis, MO, USA) and total protein concentration was determined using the Bio-Rad detergent-compatible protein assay (Bio-Rad Laboratories, Hercules, CA, USA). Akt inhibitor Ly294002 (9) and MPA were purchased from Sigma-Aldrich.

Cell culture and reagents. NRK52E cells were maintained in monolayer culture in $75 \mathrm{~cm}^{2}$ Falcon T-flasks (Thermo Fisher Scientific) containing DMEM/F-12 supplemented with $4 \%$ fetal calf serum, $15 \mathrm{mmol} / 1$ 4-(2-hydroxyethyl)-1piperazineethanesulfonic acid, $20 \mathrm{mmol} / 1$ sodium bicarbonate, $0.5 \mathrm{mmol} / 1$ sodium pyruvate, $17.5 \mathrm{mmol} / 1$ glucose, streptomycin and penicillin (Invitrogen; Thermo Fisher Scientific) at $37^{\circ} \mathrm{C}$ in an incubator with a humidified atmosphere with $5 \%$ $\mathrm{CO}_{2}$ in air. The cells were grown to $40 \%$ confluence, washed with serum and sodium pyruvate-free DMEM/F-12, and subsequently incubated with MPA or Ly294002. Untreated cells served as a control.

Experimental groups and treatments. NRK52E cells were divided into the following groups: Control group (untreated); albumin group (treated with $30 \mathrm{mg} / \mathrm{ml}$ albumin; Sigma-Aldrich); Ly294002 group (treated with $10 \mu \mathrm{mol} / 1$ Ly294002 for $30 \mathrm{~min}$ and then with $30 \mathrm{mg} / \mathrm{ml}$ albumin); and the MPA group (30 $\mathrm{mg} / \mathrm{ml}$ albumin + $10 \mu \mathrm{mol} / 1 \mathrm{MPA})$. Following incubation for $12 \mathrm{~h}$, cells were harvested for the subsequent assays.

Reverse-transcription polymerase chain reaction (RT-PCR). Total RNA was extracted from NRK52E cells using TRIzol following the manufacturer's instructions. Subsequently, $2 \mu \mathrm{g}$ total RNA was reverse-transcribed with avian myoblastosis virus reverse transcriptase (Promega Corporation, Madison, WI, USA). PCR amplification was then performed; in brief, $50 \mathrm{pmol} / \mathrm{l}$ PCR primers for $\beta$-actin and TGF- $\beta_{1}$ were added to each reaction mixture containing $0.2 \mathrm{mmol} / 1$ deoxynucleoside triphosphates (Promega Corporation), $3 \mathrm{mmol} / \mathrm{l} \mathrm{MgSO}_{4}$ and 1 U DNA polymerase (Promega Corporation). The sequences of primers were as follows: TGF- $\beta_{1}$ forward, 5'-GGCAGT GGTTGAGCCGTGGA-3' and reverse, 5'-TGTTGGACAGCT GCTCCACT-3' (590 bp); $\beta$-actin forward, 5'-TCGGACGAT ATGGAGAAGAT-3' and reverse, 5'-ATTGCCGATAGTGAT GACGT-3' (240 bp). The PCR cycling conditions were as follows: Initial denaturation at $94^{\circ} \mathrm{C}$ for $5 \mathrm{~min}$ followed by 30 cycles of $94^{\circ} \mathrm{C}$ for $1 \mathrm{~min}, 56^{\circ} \mathrm{C}$ for $1 \mathrm{~min}$ and $72^{\circ} \mathrm{C}$ for $1 \mathrm{~min}$, and a final elongation step at $72^{\circ} \mathrm{C}$ for $10 \mathrm{~min}$. The PCR was conducted using an LC480 PCR machine (Roche, Basel, Switzerland). The mRNA expression levels of the target genes were estimated by the optical density values of the bands in the agarose gels.

Western blot analysis. Following harvesting, cells were lysed in cell lysis buffer included in the N-Extract kit (Sigma-Aldrich) and the protein content was determined using a Bradford Protein Assay (Bio-Rad detergent-compatible protein assay; Bio-Rad
Laboratories). Subsequently, equal amounts of protein $(50 \mu \mathrm{g})$ were separated by $12 \%$ SDS-PAGE and electrotransferred onto a nitrocellulose membrane (EMD Millipore, Billerica, MA, USA). Following blocking with 5\% non-fat milk in phosphate-buffered saline with $0.05 \%$ Tween 20 for $30 \mathrm{~min}$ at room temperature, the membrane was incubated with rabbit anti-rat TGF- $\beta 1$ monoclonal antibody (cat. no. 3709; Cell Signaling Technology, Inc.; 1:1,000 dilution) or rabbit anti-rat Akt monoclonal antibody (cat. no. 4685; Cell Signaling Technology, Inc.; 1:2,000 dilution), followed by incubation with peroxidaseconjugated AffiniPure goat anti-rabbit IgG, (1:10,000 dilution; cat. no. 111035003; Jackson ImmunoResearch Inc., West Grove, PA, USA) secondary antibody at room temperature for $1 \mathrm{~h}$. Blots were then visualized using an enhanced chemiluminescence detection system (Active Motif, Carlsbad, CA, USA). Quantification of protein levels was performed by determining the relative optical density of the protein bands was using an image analysis system (Image J, version 1.48; National Institutes of Health, Bethesda, MD, USA).

Electrophoretic mobility shift assay (EMSA). Following the indicated treatments, NRK52E cells were assayed for NF- $\kappa$ B activation using EMSA. Nuclear extracts were hybridized with $\left[{ }^{32} \mathrm{P}\right]$-labeled oligonucleotides containing the sequence GTT GAGGGGACTTTCCCAGGC from the $\mathrm{NF}-\kappa \mathrm{B}$ promoter or a mutated NF- $\kappa \mathrm{B}$ sequence TCAACTCCCCTGAAAGGG TCCG in binding buffer (Rockland Immunochemicals, Inc., Limerick, PA, USA). These were radiolabeled with $\left[\gamma^{32} \mathrm{P}\right]$ adenosine triphosphate by T4 polynucleotide kinase for $10 \mathrm{~min}$ at $37^{\circ} \mathrm{C}$. All reactions were performed in a total volume of $20 \mu \mathrm{l}$ containing the binding buffer $[10 \mathrm{mM}$ Tris/ $\mathrm{HCl}, \mathrm{pH} 7.5$, $100 \mathrm{mM} \mathrm{NaCl}, 1 \mathrm{mM}$ EDTA, 4\% (v/v) glycerol, $5 \mathrm{mM}$ dithiothreitol and $100 \mu \mathrm{g} / \mathrm{ml}$ bovine serum albumin (Sigma-Aldrich)]. Each sample contained $2 \mu 1\left[{ }^{32} \mathrm{P}\right]$-labeled oligonucleotide and $3 \mu \mathrm{g}$ poly $(\mathrm{dI}-\mathrm{dC})$. After incubation for $15 \mathrm{~min}$ at room temperature, samples were electrophoresed on a $5 \%$ polyacrylamide gel/0.25X Tris borate EDTA (pH 8.0) (EMD Millipore). For competition experiments, unlabeled oligonucleotides were incubated with extracts for five minutes prior to the addition of radiolabeled probe. After electrophoresis, gels were dried and the protein bands were visualized using Immobilon Western HRP substrate (EMD Millipore) and autoradiographed by exposure to medical X-ray film. The obtained bands were quantified using the Luminescent Image Analyzer-LAS 4000 and Image Gauge software, version 3.1 (Fujifilm Corporation, Tokyo, Japan).

Statistical analysis. Statistical analysis was performed using SPSS, version 17.0 (SPSS, Inc., Chicago, IL, USA). Values are expressed as the mean \pm standard deviation. Significance between groups was determined using one-way analysis of variance. The Q-test was used to analyze differences in the mean values between groups. $\mathrm{P}<0.05$ was considered to indicate a statistically significant difference between values. Each experiment was repeated three times.

\section{Results}

Albumin stimulates the expression of TGF- $\beta_{1} m R N A$ and protein in rat kidney epithelial cells. Analysis of TGF- $\beta_{1}$ 
showed that NRK52E cells which were not stimulated with albumin expressed TGF- $\beta_{1}$ mRNA and protein at relatively low levels (Fig. 1). However, TGF- $\beta_{1}$ expression was significantly enhanced by albumin $(5-30 \mathrm{mg} / \mathrm{ml})$ in a dose-dependent manner $(\mathrm{P}<0.05)$.

Albumin activates $N F-\kappa B$ protein in rat kidney epithelial cells. Activation of NF- $\mathrm{kB}$ to bind to the promoter region of TGF- $\beta_{1}$ was assessed using an EMSA. As shown in Fig. 2, NRK-52E cells which were not stimulated with albumin exhibited relatively low DNA-binding activity of NF- $\mathrm{kB}$ protein, which was enhanced by albumin $(5-30 \mathrm{mg} / \mathrm{ml})$ in a dose-dependent manner with increases of up to five-fold $(\mathrm{P}<0.05)$.

MPA reduces albumin-induced Akt phosphorylation. Activation of Akt in NRK52E cells was assessed by western blot analysis using antibodies with specificity for Akt or activated p-Akt only. As shown in Fig. 3A, albumin $(5-30 \mathrm{mg} / \mathrm{ml})$ significantly activated Akt in a dose-dependent manner following $12 \mathrm{~h}$ of incubation. When cells were starved and treated with albumin $(30 \mathrm{mg} / \mathrm{ml})$ for $12 \mathrm{~h}$ in the presence of $10 \mu \mathrm{mol} / 1 \mathrm{MPA}$, the phosphorylation of Akt was significantly inhibited $(\mathrm{P}<0.05)$ (Fig. 3B), while no marked effects on the levels of total Akt protein were observed.

MPA and Akt inhibitor Ly294002 reduce albumin-induced $T G F-\beta_{1}$ expression. To test the involvement of Akt in albumin-induced TGF- $\beta_{1}$ expression in NRK52E cells, the Akt inhibitor Ly294002 was used. Cells were starved and treated with albumin $(30 \mathrm{mg} / \mathrm{ml})$ for $12 \mathrm{~h}$ in the presence of $10 \mu \mathrm{mol} / 1 \mathrm{MPA}$ or $10 \mu \mathrm{mol} / 1 \mathrm{Ly} 294002$. The results showed that Ly294002 as well as MPA significantly inhibited the expression of TGF- $\beta_{1}$ mRNA and protein (Fig. 4A and B). As Akt inhibitor Ly294002 was able to inhibit albumin-induced expression of TGF- $\beta_{1}$, it was indicated that the Akt pathway is involved in albumin-induced expression of TGF- $\beta_{1}$. It is further hypothesized that MPA may also exert its effects on albumin-induced expression of TGF- $\beta_{1}$ via the Akt pathway, which requires to be verified in future studies.

Akt inhibitor Ly294002 and MPA inhibit albumin-induced $N F-\kappa B$ activation. NRK52E cells were starved and treated with albumin $(30 \mathrm{mg} / \mathrm{ml})$ for $12 \mathrm{~h}$ in the presence of $10 \mu \mathrm{mol} / 1$ MPA or Ly294002. The stimulatory effects of albumin on the DNA-binding activity of NF- $\kappa \mathrm{B}$ were significantly blocked by Ly294002 $(\mathrm{P}<0.05)$. MPA also significantly inhibited albumin-induced NF- $\kappa \mathrm{B}$ activation $(\mathrm{P}<0.05)$ (Fig. 5). These results further confirmed that albumin exerts its effects on NF- $\mathrm{KB}$ activity via the Akt pathyway; whether MPA inhibits the activation of NF- $\kappa B$ by albumin via the Akt pathway requires to be confirmed in future studies.

\section{Discussion}

Re-absorbtion of albumin following proteinuria is closely correlated with the imbalance of proliferation/apoptosis and phenotypic differentiation of renal tubular epithelial cells, as well as the infiltration of inflammatory cells. Injured renal tubular epithelial cells cultured in vitro have a high rate of proliferation and secrete large amounts of extracellular
A
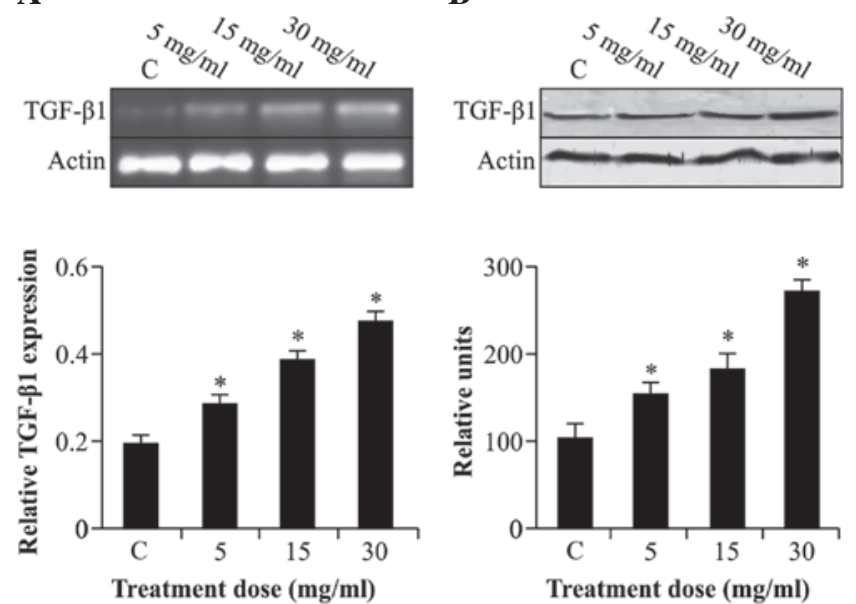

Figure 1. Effects of albumin on the expression of TGF- $\beta 1$ at the (A) mRNA and (B) protein level. Expression was significantly enhanced by albumin $(5-30 \mathrm{mg} / \mathrm{ml})$ in a dose-dependent manner. Expression levels were normalized to $\beta$-actin and values are expressed as the mean \pm standard deviation $(\mathrm{n}=3)$. ${ }^{*} \mathrm{P}<0.05$ vs. C. $\mathrm{C}$, control; TGF, transforming growth factor.
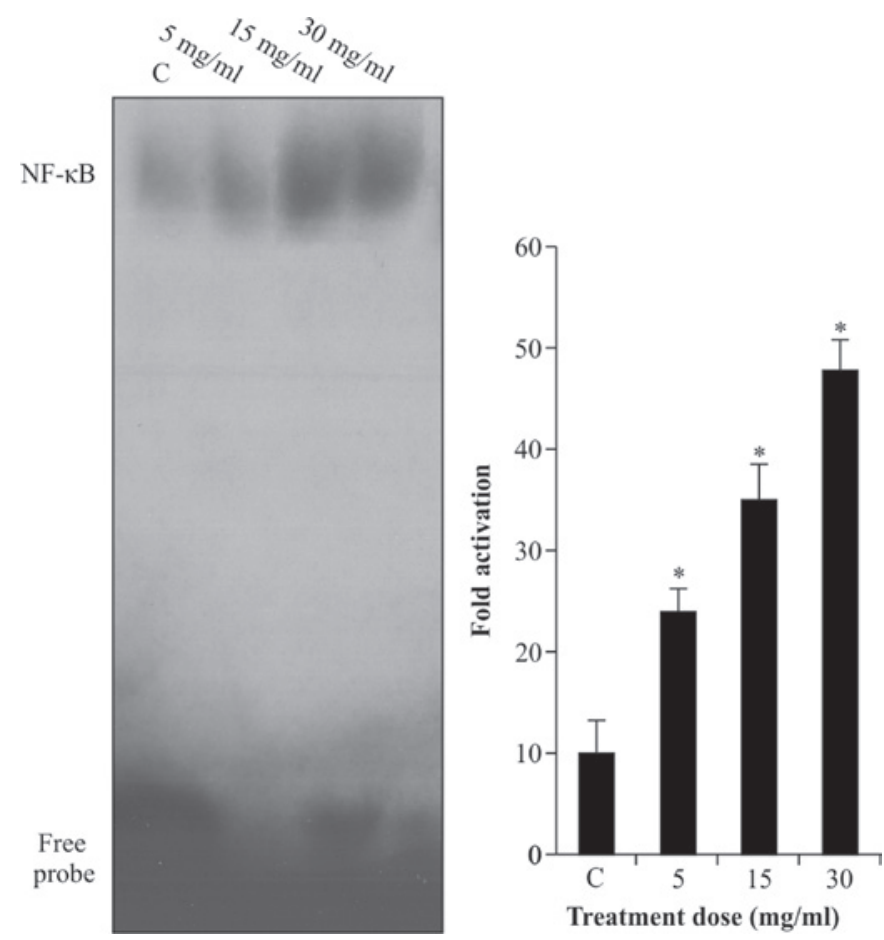

Figure 2. Effects of albumin on the binding of NF-kB protein to the promoter region of the transforming growth factor beta 1 gene. An electrophoretic mobility shift assay demonstrated that albumin stimulated the DNA-binding activity of NF- $\mathrm{KB}$ in cultured NRK52E cells in a dose-dependent manner $(5-30 \mathrm{mg} / \mathrm{ml})$. Values are expressed as the mean \pm standard deviation $(\mathrm{n}=3)$. ${ }^{*} \mathrm{P}<0.05$ vs. C. C, control; NF, nuclear factor.

matrix, which results in fibrosis (1). Simultaneously, the injured renal cells transdifferentiate into muscular fibroblasts which secrete large amounts of growth factors, thereby amplifying the local immunoinflammatory reaction and accelerating the process of fibrosis $(11,12)$. Proteinuria is a well-known exacerbating factor in renal tubular interstitial disease (13). Renal interstitial fibrosis is a common pathological process in progressive renal diseases, which leads to 
A
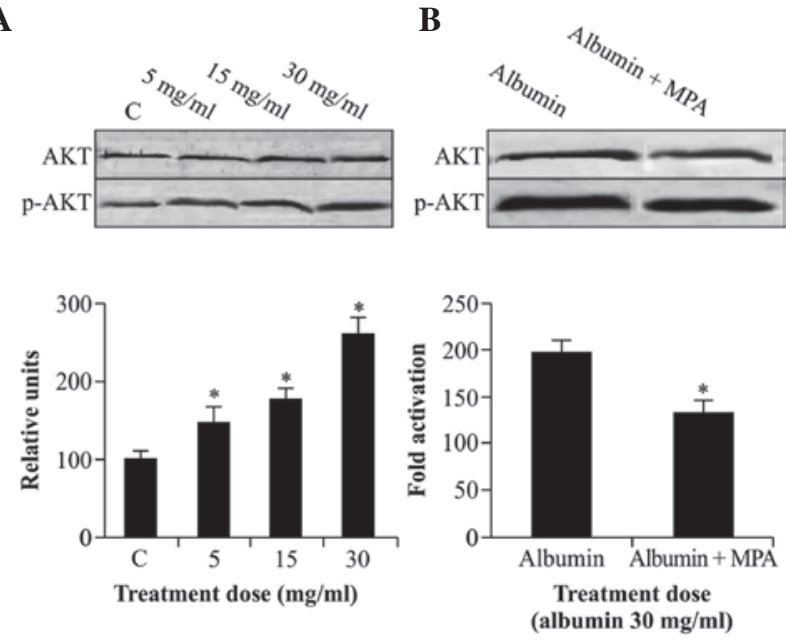

Figure 3. Effects of MPA on Akt phosphorylation. (A) Activation of Akt was assessed by western blot analysis using p-Akt-specific antibodies. ${ }^{*} \mathrm{P}<0.05$ vs. C. (B) The phosphorylation of Akt was inhibited by $10 \mu \mathrm{M}$ MPA $($ " $\mathrm{P}<0.05$ vs. albumin only), while total Akt was not affected. Values are expressed as the mean \pm standard deviation $(\mathrm{n}=3)$. C, control; MPA, mycophenolic acid; p-Akt, phosphorylated Akt.
A
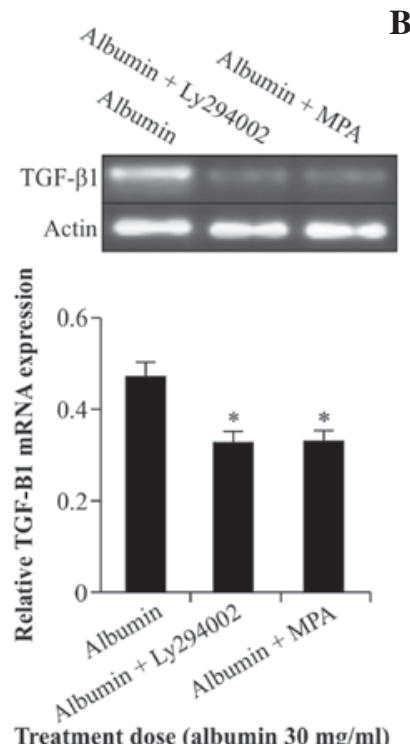

B
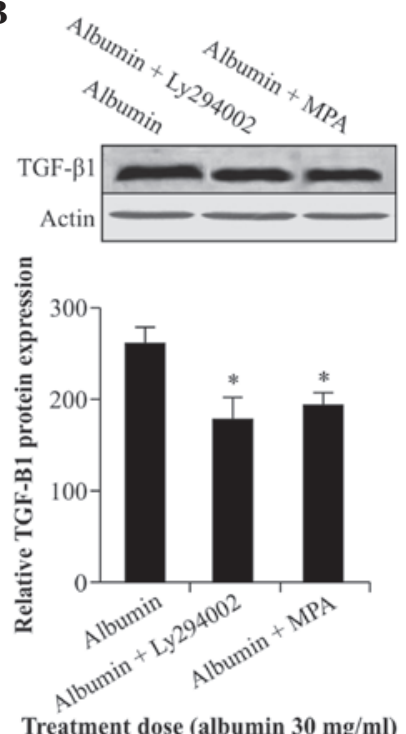

Figure 4. Effects of Ly294002 and MPA on albumin-induced TGF- $\beta_{1}$ expression. Ly294002 and MPA significantly inhibited the (A) mRNA and (B) protein expression of TGF- $\beta_{1} \cdot \beta$-actin was used as an internal standard. Values are expressed as the mean \pm standard deviation $(n=3) .{ }^{*} \mathrm{P}<0.05$ vs albumin. TGF, transforming growth factor; MPA, mycophenolic acid.

functional deterioration of renal cells and eventual loss of renal function (14-17).

MPA, the active metabolite of MMF, is a potent, non-competitive and reversible inhibitor of inosine-5'-monophosphate dehydrogenase, the rate-limiting enzyme for de novo purine synthesis. MPA has an effect on cell growth and chemokine release of tubular epithelial cells, and these effects are dependent on the inhibition of cellular guanosine production. However, limited data are available on the effects of MPA on renal tubular epithelial cells $(4,18)$.

TGF- $\beta_{1}$ is a fibrogenic and inflammatory cytokine with a central role in the pathogenesis of renal fibrosis (19). It has
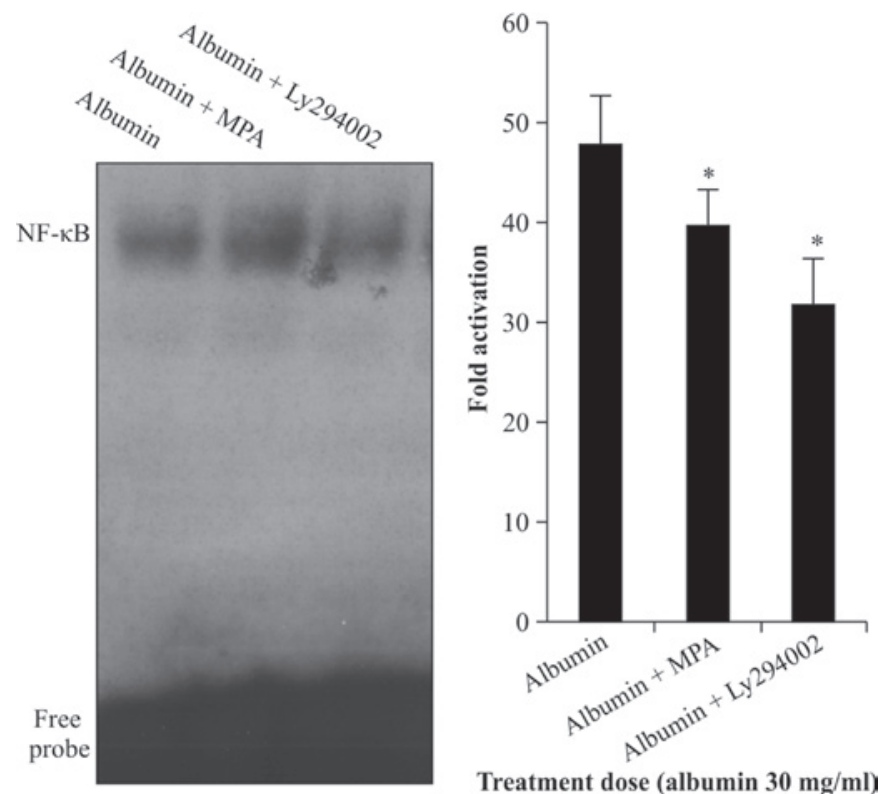

Figure 5. Effects of Ly294002 and MPA on albumin-induced binding of $\mathrm{NF}-\mathrm{\kappa B}$ to the promoter region of transforming growth factor beta 1 . An electrophoretic mobility shift assay showed that the stimulatory effect of albumin on NF- $\mathrm{kB}$ was blocked by Ly294002. MPA also significantly inhibited albumin-induced NF- $\mathrm{KB}$ activation. Values are expressed as the mean \pm standard deviation $(\mathrm{n}=3)$. ${ }^{*} \mathrm{P}<0.05$ vs. albumin only. NF, nuclear factor; MPA, mycophenolic acid.

been demonstrated that treatment with TGF- $\beta_{1}$ antibody restrained the function of TGF- $\beta_{1}$ to reduce the degree of tubular fibrosis (20). A further study showed that intraperitoneal injection of TGF- $\beta$ induced renal fibrosis in mice (21). In the present study, albumin was shown to stimulate the expression of TGF- $\beta_{1}$ in tubular epithelial cells in a dose-dependent manner, indicating that albumin triggers mechanisms in renal tubular epithelial cells leading to fibrotic injury. This mechanism may be the underlying reason for proteinuria causing renal interstitial fibrosis. Furthermore, the present study demonstrated that MPA inhibited TGF- $\beta_{1}$ expression, thereby potentially preventing fibrotic injury.

The promoter region of the TGF- $\beta_{1}$ gene contains $\mathrm{NF}-\kappa \mathrm{B}$-binding sites. NF- $\kappa \mathrm{B}$ is a transcription factor which consists of a 550 and a p65 sub-unit. NF- $\kappa \mathrm{B}$ regulates the production of pro-inflammatory mediators in cellular inflammation. Activation of $\mathrm{NF}-\kappa \mathrm{B}$ drives renal inflammation and fibrosis (22). In the resting stage, $\mathrm{NF}-\kappa \mathrm{B}$ exists in its inactive form in the cytoplasm; however, it becomes activated when cells are stimulated (23). The present study revealed that albumin overload can stimulated the binding activity of $\mathrm{NF}-\kappa \mathrm{B}$ to the promoter region of TGF- $\beta_{1}$. Furthermore, MPA was able to inhibit albumin-induced activation of $\mathrm{NF}-\kappa \mathrm{B}$ protein.

Akt is a serine/threonine protein kinase which is mainly responsible for the initiation of biological signal transmission by PI3K. Akt is in the central axis of the Akt/PI3K pathway, with its functions including cell cycle regulation, induction of apoptosis, and the participation in numerous important physiological and pathological process, including angiogenesis, telomerase activity and malignant characteristics of cells (24). Akt also regulates cell activation and proliferation through $\mathrm{NF}-\kappa \mathrm{B}(25)$. It has been reported that Akt increases the 


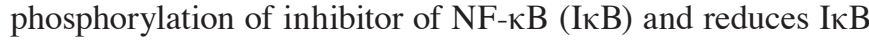
protein synthesis to activate the NF- $\kappa \mathrm{B}$. Abnormal activation of Akt has an important role in processes leading to renal fibrosis (26). The present study suggested that albumin significantly enhanced the level of Akt activation in NRK52E cells following $12 \mathrm{~h}$ in a dose-dependent manner. This result suggested that Akt phosphorylation has an important role in processes of renal tubular epithelial cell injury. Treatment with Ly294002, a specific inhibitor of Akt, inhibited the expression of TGF- $\beta_{1}$ and activation of binding of NF- $\kappa \mathrm{B}$ to the promoter region of TGF- $\beta_{1}$. This result indicated that albumin induced the synthesis of TGF- $\beta_{1}$ and the activation of NF- $\mathrm{KB}$ in tubular epithelial cells partly through the phosphorylation of Akt.

The present study showed that albumin significantly increased TGF- $\beta_{1}$ expression and NF- $\kappa \mathrm{B}$ activation. Furthermore, MPA and Ly294002 inhibited TGF- $\beta_{1}$ expression and NF- $\kappa \mathrm{B}$ activation. In addition albumin significantly enhanced Akt activation, which was inhibited by MPA. The observation that the Akt inhibitor effectively inhibited albumin-induced TGF- $\beta_{1}$ expression and NF- $\kappa \mathrm{B}$ activation leads to the hypothesis that MPA exerts its anti-fibrotic effects, at least partially, by inhibiting Akt activation; however, this remains to be experimentally verified in future studies.

In conclusion, the present study demonstrated that MPA inhibited albumin-induced TGF- $\beta_{1}$ expression and the binding of NF- $\mathrm{KB}$ to the promoter region of TGF- $\beta_{1}$, possibly through inhibiting Akt activation.

\section{Acknowledgements}

The current study was supported by the Key Foundation of Hubei Nature Scientific Funds (grant no. 2013CFB227).

\section{References}

1. Abbate M, Zoja C and Remuzzi G: How does proteinuria cause progressive renal damage. J Am Soc Nephrol 17: 2974-2984, 2006.

2. Waller JR, Brook NR, Bicknell GR, Murphy GJ and Nicholson ML: Mycophenolate mofetil inhibits intimal hyperplasia and attenuates the expression of genes favouring smooth muscle cell proliferation and migration. Transplant Proc 37: 164-166, 2005

3. Roos N, Poulalhon N, Farge D, Madelaine I, Mauviel A and Verrecchia F: In vitro evidence for a direct antifibrotic role of the immunosuppressive drug mycophenolate mofetil. J Pharmacol Exp Ther 321: 583-589, 2007.

4. Petrova DT, Brandhorst G, Brehmer F, Gross O, Oellerich M and Armstrong VW: Mycophenolic acid displays IMPDH-dependent and IMPDH-independent effects on renal fibroblast proliferation and function. Ther Drug Monit 32: 405-412, 2010.

5. Guo $X$ and Wang XF: Signaling cross-talk between TGF-beta/BMP and other pathways. Cell Res 19: 71-88, 2009.

6. Assinder SJ, Dong Q, Kovacevic Z and Richardson DR: The TGF-beta, PI3K/Akt and PTEN pathways: Established and proposed biochemical integration in prostate cancer. Biochem J 417: 411-421, 2009.
7. Danielpour D: Functions and regulation of transforming growth factor-beta (TGF-beta) in the prostate. Eur J Cancer 41: 846-857, 2005.

8. Nowak DE, Tian B, Jamaluddin M, Boldogh I, Vergara LA, Choudhary S and Brasier AR: RelA Ser276 phosphorylation is required for activation of a subset of NF-kappaB-dependent genes by recruiting cyclin-dependent kinase 9/cyclin T1 complexes. Mol Cell Biol 28: 3623-3638, 2008.

9. Dummler B and Hemmings BA: Physiological roles of PKB/Akt isoforms in development and disease. Biochem Soc Trans 35: 231-235, 2007.

10. Takase O, Marumo T, Imai N, Hirahashi J, Takayanagi A, Hishikawa K, Hayashi M, Shimizu N, Fujita T and Saruta T: NF-kappaB-dependent increase in intrarenal angiotensin II induced by proteinuria. Kidney Int 68: 464-473, 2005.

11. Burton CJ, Harper SJ, Bailey E, Feehally J, Harris KP and Walls J: Turnover of human tubular cells exposed to proteins in vivo and in vitro. Kidney Int 59: 507-514, 2001.

12. Strutz F, Zeisberg M, Ziyadeh FN, Yang CQ, Kalluri R, Müller GA and Neilson EG: Role of basic fibroblast growth factor-2 in epithelial-mesenchymal transformation. Kidney Int 61: 1714-1728, 2002.

13. Tareeva IE, Kutyrina IM, Nikolaev Alu, Lifshits NL and Shvetsov MIu: Ways to inhibit development of chronic renal failure. Ter Arkh 72: 9-14, 2000 (In Russian).

14. Li MX and Liu BC: Epithelial to mesenchymal transition in the progression of tubulointerstitial fibrosis. Chin Med J (Engl) 120: 1925-1930, 2007.

15. Eddy AA: Molecular basis of renal fibrosis. Pediatr Nephrol 15: 290-301, 2000.

16. Klahr S and Morrissey J: Progression of chronic renal disease. Am J Kidney Dis 41 (3 Suppl 1): S3-S7, 2003.

17. Owen WF Jr: Patterns of care for patients with chronic kidney disease in the United States: Dying for improvement. J Am Soc Nephrol 14 (7 Suppl 2): S76-S80, 2003.

18. Baer PC, Gauer S, Hauser IA, Scherberich JE and Geiger H: Effects of mycophenolic acid on human renal proximal and distal tubular cells in vitro. Nephrol Dial Transplant 15: 184-190, 2000.

19. Qi W, Chen X, Poronnik P and Pollock CA: Transforming growth factor-beta/connective tissue growth factor axis in the kidney. Int J Biochem Cell Biol 40: 9-13, 2008.

20. Isaka Y, Tsujie M, Ando Y, Nakamura H, Kaneda Y, Imai E and Hori M: Transforming growth factor-beta 1 antisense oligodeoxynucleotides block interstitial fibrosis in unilateral ureteral obstruction. Kidney Int 58: 1885-1892, 2000.

21. Samarakoon R, Overstreet JM, Higgins SP and Higgins PJ: $\mathrm{TGF}-\beta 1 \rightarrow \mathrm{SMAD} / \mathrm{p} 53 / \mathrm{USF} 2 \rightarrow \mathrm{PAI}-1$ transcriptional axis in ureteral obstruction-induced renal fibrosis. Cell Tissue Res 347: 117-128, 2012.

22. Ma FY, Tesch GH, Ozols E, Xie M, Schneider MD and Nikolic-Paterson DJ: TGF- $\beta 1$-activated kinase- 1 regulates inflammation and fibrosis in the obstructed kidney. Am J Physiol Renal Physiol 300: F1410-F1421, 2011

23. Chen ZJ: Ubiquitin signalling in the NF-kappaB pathway. Nat Cell Biol 7: 758-765, 2005.

24. Hirai K, Hayashi T, Chan PH, Zeng J, Yang GY, Basus VJ, James TL and Litt L: PI3K inhibition in neonatal rat brain slices during and after hypoxia reduces phospho-Akt and increases cytosolic cytochrome c and apoptosis. Brain Res Mol Brain Res 124: 51-61, 2004.

25. Zdychová J and Komers R: Emerging role of Akt kinase/protein kinase B signaling in pathophysiology of diabetes and its complications. Physiol Res 54: 1-16, 2005.

26. Runyan CE, Schnaper HW and Poncelet AC: The phosphatidylinositol 3-kinase/Akt pathway enhances Smad3-stimulated mesangial cell collagen I expression in response to transforming growth factor-beta1. J Biol Chem 279: 2632-2639, 2004. 